\title{
Pengaruh Keterampilan, Pengetahuan dan Karakter Pada Tingkat Profesionalisme Dosen di Perguruan Tinggi
}

\author{
I Gusti Ngurah Abiana ${ }^{1}$ \\ Ni Ketut Rasmini ${ }^{2}$ \\ ${ }^{1,2}$ Fakultas Ekonomi dan Bisnis Universitas Udayana (Unud), Bali, Indonesia \\ e-mail: ngurahabiana01@gmail.com
}

\begin{abstract}
ABSTRAK
Profesionalisme adalah suatu sifat, kemahiran, keahlian dan cara pelaksanaan suatu hal yang dilakukan oleh seorang profesional. Seorang dosen sangat mutlak memerlukan profesionalisme yang cukup karena adanya suatu tuntutan terutama dosen akuntansi bahwa apabila dosen tersebut tidak profesional maka akan menghasilkan akuntan yang juga tidak professional. Tujuan dari penelitian ini adalah untuk menganalisis pengaruh keterampilan, pengetahuan, dan karakter terhadap persepsi mahasiswa mengenai profesionalisme dosen. Sampel penelitian ini adalah mahasiswa prodi akuntansi Fakultas Ekonomi dan Bisnis Universitas Udayana dengan jumlah responden sebanyak 171 orang. Menggunakan metode sampel stratified random sampling dan pengumpulan data menggunakan kuesioner. Data dianalisis dengan menggunakan analisis Regresi Linier Berganda. Hasil analisis menunjukkan bahwa keterampilan, pengetahuan, dan karakter berpengaruh positif pada persepsi mahasiswa mengenai profesionalisme dosen.
\end{abstract}

Kata kunci: Keterampilan, pengetahuan, karakter, profesionalisme.

\begin{abstract}
Professionalism is a trait, skill, and way of implementing things done by a professional. A lecturer is absolutely in need of sufficient professionalism because there is a demand, especially the accounting lecturer that if the lecturer is not professional it will produce accountants who are also unprofessional. The purpose of this study was to analyze the influence of skills, knowledge, and character on student perceptions of the professionalism of lecturers. The sample of this study is accounting students, Faculty of Economics and Business, Udayana University, with 171 respondents. This study uses a stratified random sampling method and data collection using a questionnaire. Data is analyzed using multiple linear regression analysis. The results of the analysis show that the skill, knowledge, and character have a positive effect and on the students' perceptions of the lecturers professionalism.
\end{abstract}

Keywords: Skills, knowledge, character, professionalism.

\section{PENDAHULUAN}

Pendidikan merupakan suatu hal yang menjembatani seseorang untuk menuju kesuksesan dan kemajuan bersama di berbagai bidang. Dalam usaha pembangunan sumber daya yang bersaing maka mutu dan kualitas pendidikan menjadi faktor yang riskan dan sangat penting untuk terus ditingkatkan. 
Peningkatan tersebut dapat diraih melalui peningkatan profesionalisme tenaga pendidik. Usaha pembangunan dan peningkatan kualitas sumber daya manusia, kualitas pendidikan merupakan hal yang sangat berpengaruh dan signifikan. Melalui pendidikan mahasiswa mendapatkan sebuah pondasi yang akan menjadi kemampuan dasar mereka.

Universitas merupakan salah satu media pendidik yang berperan sangat besar dalam pendidikan untuk peningkatan kemampuan sumber daya manusia, melalui universitas mahasiswa mendapatkan pendidikan yang lebih kompleks dan mendalam. Safford and Kershaw (1998) berpendapat bahwa institusi pendidikan tinggi harus melakukan transformasi secara struktural maupun sistemik dengan melakukan pelatihan dan cara-cara lain untuk meningkatkan profesionalisme, baik terhadap staf akademik maupun nonakademik. Dengan profesionalisme yang memadai, maka akan tercipta suatu proses pembelajaran yang kondusif dalam rangka mengantarkan mahasiswa menjadi akuntan profesional. Melalui pendidikan dan pengetahuan yang di dapat dalam perguruan tinggi tentu mahasiswa memiliki suatu persepsi mengenai tingkat ke-profesionalismean suatu dosen dalam hal yang lebih spesifik, dosen akuntansi.

Profesionalisme merupakan suatu keharusan bagi anggota organisasi untuk mampu menjaga kredibilitas baik di saat ini maupun di saat yang akan datang. Dimana persaingan semakin sengit di segala bidang, termasuk di bidang pendidikan, oleh karena itu Perguruan Tinggi dituntut untuk melakukan persiapan yang cukup. Salah satu persiapan tersebut merupakan profesionalisme para dosen yang mengajar di Perguruan Tinggi tersebut (Nurchayati, 2012). 
Persepsi pada dasarnya merupakan suatu proses dengan mana individuindividu mengorganisasikan dan menafsirkan kesan indera mereka agar memberi makna kepada lingkungan mereka, Robbins (2001:88). Persepsi adalah tindakan menyusun, mengenali, dan menafsirkan informasi sensoris guna memberikan gambaran dan pemahaman tentang lingkungan (Alizamar, 2017:9). Persepsi juga mengarah pada sudut pandang seseorang terhadap sesuatu atau seseorang dan berbeda antara satu orang dengan orang lainnya. Persepsi dipengaruhi oleh pengalaman, lingkungan dan juga emosi.

Profesionalisme adalah suatu sifat, kemahiran, keahlian dan cara pelaksanaan suatu hal yang dilakukan oleh seorang profesional.Profesional menurut Novin \& Tucker $(1993 ; 281)$ adalah penguasaan dan pelaksanaan dari : keterampilan (skill), pengetahuan (knowledge), dan karakter (character). Seorang dosen sangat mutlak memerlukan profesionalisme yang cukup karena adanya suatu tuntutan terutama dosen akuntansi bahwa apabila dosen tersebut tidak profesional maka akan menghasilkan akuntan yang juga tidak professional. Dalam penelitian ini tingkat keprofesionalismean seorang dosen dilihat dari faktor ekstrenal dan internal, hal-hal yang berkaitan dengan faktor eksternal ini ditentukan melalui penilaian mahasiswa, sedangkan faktor internal ini ditentukan oleh sikap dan karakter dari seorang dosen. Dalam usaha peningkatan kualitas sumber daya manusia ini, semua aspek harus sangat diperhatikan dan harus saling mendukung satu sama lain.

Keterampilan adalah kemampuan untuk menggunakan akal, pikiran, ide dan kreatifitas untuk mengerjakan atau melakukan sesuatu menjadi lebih 
bermakna sehingga menghasilkan sebuah nilai dari hasil pekerjaan tersebut (Tarigan, 2017:87). Keterampilan menurut (Nurchayati, 2012) memiliki pengaruh negatif terhadap persepsi mahasiswa tentang profesionalisme dosen akuntansi, selain itu Virgana (2014) juga menyebutkan bahwa keterampilan memiliki pengaruh negatif terhadap tingkat persepsi mahasiswa tentang tingkat profesionalisme dosen akuntansi. Pramesti dan Palupi (2016) menyatakan bahwa keterampilan memiliki pengaruh positif terhadap persepsi mahasiswa tentang tingkat profesionalisme dosen akuntansi di perguruan tinggi di Surakarta, Pramesti dan Dhewi (2016) juga memperoleh hasil yang menyatakan keterampilan memiliki pengaruh positif terhadap persepsi mahasiswa tentang tingkat profesionalisme dosen akuntansi. Jadi dari beberapa penelitian empiris yang dilakukan tersebut terdapat variasi hasil yang diperoleh dan diharapkan penelitian ini dapat dijadikan acuan untuk melihat variasi persepsi mahasiswa tentang keterampilan dosen akuntansi di Universitas Udayana. Jadi melalui keterampilan yang andal diharapkan dosen akuntansi dapat membantu mahasiswa untuk meningkatkan kemampuan dan juga meningkatkan indeks prestasi komulatif mahasiswa.

Pengetahuan adalah kumpulan dari segala informasi baik informasi umum atau informasi yang lebih spesifik bidangnya, pengetahuan terbentuk melalui pengalaman dalam kehidupan, hal ini juga di dapat melalui pendidikan formal. Pengetahuan menurut Pramesti dan Dhewi (2016) memiliki pengaruh negatif terhadap persepsi mahasiswa tentang tingkat profesionalisme dosen akuntansi di Jawa Tengah. Berbeda halnya dengan Arifin (2015) menyatakan bahwa 
pengetahuan memiliki pengaruh positif terhadap persepsi mahasiswa tentang profesionalisme dosen akuntansi, disamping itu Riddiniyah (2013) juga menyatakan bahwa pengetahuan memiliki pengaruh positif terhadap persepsi mahasiswa tentang tingkat profesionalisme dosen. Berdasarkan hasil pengujian yang variatif tersebut maka penelitian ini dibuat untuk mengkaji lebih dalam tentang hubungan antara pengetahuan terhadap persepsi mahasiswa tentang tingkat profesionalisme dosen akuntansi di Universitas Udayana. Kemudian diharapkan melalui pengetahuan yang luas tidak hanya di bidang akuntansi saja melainkan juga pengetahuan bisnis dan pengetahuan kewirausahaan, pengetahuan dosen akuntansi dapat membantu untuk meningkatkan indeks prestasi kumulatif mahasiswa.

Karakter adalah sifat yang mendasari setiap kelakuan seseorang, karakter meliputi etika, sikap, cara bertindak, cara berbicara dan integritas. Karakter dapat terbentuk dari pengalaman seseorang, lewat emosi seseorang terhadap apa yang telah individu tersebut alami. Menurut Mulyani (2015) karakteristik memiliki pengaruh negatif terhadap persepsi mahasiswa tentang tingkat profesionalisme dosen akuntansi, menurut Nurdin (2013) karakter memiliki pengaruh negatif terhadap persepsi mahasiswa tentang tingkat profesionalisme dosen akuntansi di pada Perguruan Tinggi di Makasar. Menurut Rahmalia (2013) carracteristic memiliki pengaruh positif terhadap kualitas akuntan pendidik menghadapi tuntutan profesionalisme. Menurut Idrus (2013) karakter memiliki pengaruh positif tentang profesionalisme dosen akuntansi dan metode mengajar terhadap terhadap tingkat prestasi mahasiswa. melalui penilaian yang variatif tersebut 
penilitian ini di harapkan dapat digunakan untuk menguji dan memperoleh data empiris tentang persepsi mahasiswa terhadap tingkat profesionalisme dosen akuntansi di Universitas Udayana, kemudian melalui karakteristik dosen diharapkan dapat membantu mengembangkan sikap mahasiswa yang kreatif, imajinatif dan mampu bersaing namun tetap mengedepankan kesopanan dan norma yang berlaku dan juga mampu membantu mahasiswa meningkatkan indeks prestasi komulatif.

Melalui sumber daya manusia yang baik maka diharapkan nantinya akan menumbuhkan tingkat persaingan masyarakat nasional dengan masyarakat dunia yang dimana perkembangan telah terjadi diseluruh dunia dan kita tidak bisa hanya duduk diam melihat saja, agar tidak tergerus oleh jaman dan kalah saing maka dari itu diperlukan kesadaran dari berbagai elemen tidak hanya dari dunia pendidikan saja tetapi dari segala faktor dan elemen yang ada di masyarakat untuk mau membantu pengembangan kemampuan bersaing kualitas sumber daya manusia kita dan untuk memiliki kemauan untuk kebaikan bersama demi terciptanya masyarakat yang sejahtera.

Keterampilan adalah suatu kemampuan dasar yang dimiliki seseorang dimana keterampilan ini dapat di gunakan dalam berbagai hal dalam kehidupan seseorang. Pada penelitian ini keterampilan yang dimaksud adalah keterampilan dalam dunia pendidikan, hal ini meliputi, kemampuan berpikir, kemampuan memecahkan masalah, keterampilan berbicara dan mendengar serta keterampilan dalam menggunakan komputer. Jadi melalui keterampilan yang baik dalam hal berpikir, memecahkan masalah, berbicara, mendengar dan komputer, seorang 
dosen dapat dikatakan sudah melakukan hal yang sewajarnya dilakukan oleh seorang profesional.

Melalui keterampilan dosen yang baik diharapkan mahasiswa dapat meningkatkan keterampilan mereka, dan diharapkan melalui keterampilan yang andal mahasiswa dapat meningkatkan indeks prestasi kumulatif. Menurut Pramesti dan Palupi (2016) keterampilan memiliki pengaruh positif terhadap persepsi mahasiswa tentang profesionalisme dosen akuntansi di Perguruan Tinggi Surakarta. Menurut Anggraeni (2016) pengetahuan memiliki pengaruh positif terhadap persepsi mahasiswsa tentang profesionalisme dosen akuntansi di perguruan tinggi di Surakarta. Menurut Virgana (2014) keterampilan berpengaruh positif terhadap persepsi mahasiswa tentang tingkat profesionalisme dosen akuntansi. Berdasarkan uraian diatas, maka hipotesis yang dapat dikembangkan dalam penelitian ini adalah sebagai berikut:

$\mathrm{H}_{1}$ : Keterampilan berpengaruh positif pada persepsi mahasiswa tentang tingkat profesionalisme dosen akuntansi Universitas Udayana.

Pengetahuan adalah kumpulan dari segala informasi baik informasi umum atau informasi yang lebih spesifik bidangnya, pengetahuan terbentuk melalui pengalaman dalam kehidupan, hal ini juga di dapat melalui pendidikan formal. Pada penelitian ini pengetahuan yang dimaksud adalah pengetahuan umum, pengetahuan bisnis dan pengetahuan pendidikan akuntansi. Melalui pengetahuan yang luas tidak hanya dalam bidang akuntansi saja melainkan dalam pengetahuan umum dan bisnis juga, diharapkan hal tersebut akan meningkatkan persepsi mahasiswa tentang tingkat profesionalisme dosen akuntansi Universitas Udayana, 
dan akan juga mempengaruhi peningkatan indeks prestasi kumulatif mahasiswa prodi akuntansi di Universitas Udayana.

Pengetahuan berpengaruh positif terhadap persepsi mahasiswa tentang tingkat profesionalisme dosen akuntans di perguruan tinggi di Surakarta (Pramesti dan Palupi, 2016). Menurut Nurchayati (2012) pengetahuan berpengaruh positif terhadap terhadap persepsi mahasiswa tentang profesionalisme dosen akuntansi fakultas ekonomi Universitas 17 Agustus 1945 Semarang. Menurut Istiqomah (2015) pengetahuan berpengaruh positif terhadap persepsi mahasiswa tentang tingkat profesionalisme dosen akuntansi. Berdasarkan uraian diatas, maka hipotesis yang dapat dikembangkan dalam penelitian ini adalah sebagai berikut:

$\mathrm{H}_{2}$ : Pengetahuan berpengaruh positif pada persepsi mahasiswa tentang tingkat profesionalisme dosen akuntansi Universitas Udayana.

Karakter adalah suatu hal yang mendasari setiap perbuatan kita, karakter mencerminkan kebiasaan yang kita lakukan sehari-hari. Karakter seseorang tentu berbeda dengan yang lainnya, namun ada pula yang sama. Karakter juga terbentuk melalui pengalaman dan emosi. Dalam penelitian ini karakter yang dimaksud adalah cara seorang dosen beradaptasi dengan mahasiswa dan etika. Melalui karakter yang kuat dan sopan diharapkan hal ini akan meningkatkan persepsi mahasiswa tentang tingkat profesionalisme dosen akuntansi dan juga melalui karakter diharapkan mahasiswa dapat tetap memegang teguh setiap tindakan mereka berdasarkan etika dan moral yang berlaku ditengah perubahan jaman yang begitu kuat serta mampu meningkatkan indeks prestasi kumulatif mahasiswa.

Penelitian yang dilakukan Mulyani (2015) karakteristik berpengaruh positif terhadap persepsi mahasiswa tentang tingkat profesionalisme dosen 
akuntansi. Menurut Nurdin (2013) karakter berpengaruh positif terhadap persepsi mahasiswa akuntansi terntangprofesionalisme dosen akuntansi pada perguruan tinggi di Makasar. Menurut Idrus (2013) karakter berpengaruh positif terhadap persepsi mahasiswa tentangprofesionalisme dosen akuntansi dan metode pembelajaran terhadap tingkat prestasi mahasiswa. Berdasarkan uraian diatas, maka hipotesis yang dapat dikembangkan dalam penelitian ini adalah sebagai berikut:

$\mathrm{H}_{3}$ : Karakter berpengaruh positif pada persepsi mahasiswa tentang tingkat profesionalisme dosen akuntansi Universitas Udayana.

\section{METODE PENELITIAN}

Penelitian ini dilakukan di Fakultas Ekonomi Dan Bisnis (FEB) Universitas Udayana yang beralamat di jalan P.B. Sudirman Denpasar, Bali, Indonesia.Objek dalam penelitian ini adalah persepsi mahasiswa tentang tingkat profesionalisme dosen akuntansi, khususnya tentang keterampilan, pengetahuan dan karakter.

Populasi dalam penelitian ini adalah seluruh mahasiswa akuntansi regular pagi dan regular sore Fakultas Ekonomi Dan Bisnis Universitas Udayana Angkatan 2015 yang masih aktif kuliah. Berikut jumlah populasi yang digunakan pada penelitian ini disajikan pada Tabel 1 sebagai berikut:

Tabel 1.

Jumlah Mahasiswa Prodi Akuntansi Angkatan 2015

\begin{tabular}{ccc}
\hline No & Kelas & Jumlah \\
\hline 1 & Reguler Pagi & 146 \\
2 & Reguler Sore & 152 \\
& Total & 298 \\
\hline
\end{tabular}

Sumber :Fakultas Ekonomi Dan Bisnis Universitas Udayana, 2018

Sampel penelitian ini adalah mahasiswa akuntansi regular pagi dan regular sore Fakultas Ekonomi Dan Bisnis Universitas Udayana Angkatan 2015 yang 
masih aktif kuliah.Teknik pengumpulan sampel yang digunakan adalah metode stratified random sampling yaitu metode yang dimana dilakukan klasifikasi terlebih dahulu yang dibagi menurut program kuliah meliputi program regular pagi dan program regular sore. Dalam menentukan jumlah sampel peneliti menggunakan rumus Slovin, yaitu:

$$
n=\frac{N}{\left(1+N e^{2}\right)}
$$

$\mathrm{n}=$ jumlah anggota sampel

$\mathrm{N}=$ jumlah anggota populasi

$\mathrm{e}=$ nilai kritis (batas ketelitian 0,05)

perhitungan sampel :

$$
n=\frac{298}{\left(1+298(0,05)^{2}\right)}
$$

$\mathrm{n}=170,77$ dibulatkan 171

Tabel 2.

Jumlah sampel pada masing-masing program

\begin{tabular}{ccc}
\hline Program & Perhitungan & Hasil \\
\hline Reguler Pagi & $146 / 298 \times 171=83,7$ & 84 \\
Reguler Sore & $152 / 298 \times 171=87,2$ & 87 \\
& Total & 171 \\
\hline
\end{tabular}

Sumber: Data diolah, 2018

Teknik analisis yang digunakan dalam penelitian ini adalah Teknik analisis regresi linier berganda. Model regresi linier berganda ini dirmuskan sebagai berikut.

$Y=\alpha+\beta_{1} X_{1}+\beta_{2} X_{2}+\beta_{3} X_{3}+e$

Keterangan :

$\mathrm{Y}=$ Tingkat Profesionalisme Dosen Akuntansi

$\alpha=$ Konstanta

$\beta_{1}=$ Koefisien regresi keterampilan

$\beta_{2}=$ Koefisien regresi pengetahuan

$\beta_{3}=$ Koefisien regresi karakter

$\mathrm{X}_{1}=$ Keterampilan

$\mathrm{X}_{2}=$ Pengetahuan 


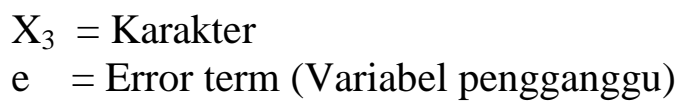

\section{HASIL DAN PEMBAHASAN}

Karakteristik responden yang diteliti meliputi jenis kelamin, program studi dan indeks prestasi komulatif. Karakteristik responden disajikan pada Tabel 3.

Tabel 3.

\section{Karakteristik Responden}

\begin{tabular}{|c|c|c|c|c|}
\hline No. & Kriteria & Keterangan & $\begin{array}{l}\text { Jumlah } \\
\text { (orang) }\end{array}$ & $\begin{array}{c}\text { Persentase } \\
(\%)\end{array}$ \\
\hline \multirow{2}{*}{1} & Jenis & Laki-laki & 83 & 48,5 \\
\hline & Kelamin & Perempuan & 88 & 51,5 \\
\hline \multicolumn{3}{|c|}{ Jumlah } & 171 & 100 \\
\hline \multirow{3}{*}{2} & \multirow{2}{*}{ Program } & Reguler Pagi & 86 & 50,3 \\
\hline & & Reguler Sore & 85 & 49,7 \\
\hline & \multicolumn{2}{|c|}{ Jumlah } & 171 & 100 \\
\hline \multirow{4}{*}{3} & \multirow{4}{*}{ IPK } & \multicolumn{2}{|c|}{ Rata-rata IPK Laki-laki (Reguler Pagi) } & 3,49 \\
\hline & & \multicolumn{2}{|c|}{ Rata-rata IPK Perempuan (Reguler Pagi) } & 3,65 \\
\hline & & \multicolumn{2}{|c|}{ Rata-rata IPK Laki-laki (Reguler Sore) } & 3,57 \\
\hline & & \multicolumn{2}{|c|}{ Rata-rata IPK Perempuan (Reguler Sore) } & 3,48 \\
\hline
\end{tabular}

Sumber: Data diolah, 2018

Berdasarkan Tabel 3 data karakteristik responden yang meliputi jenis kelamin, program, dan IPK dapat diuraikan sebagai berikut.

Karakteristik responden berdasarkan jenis kelamin menjelaskan mengenai proporsi mahasiswa laki-laki dan perempuan. Tabel 3 menunjukkan bahwa responden laki-laki sebanyak 83 orang $(48,5 \%)$ dan jumlah responden perempuan sebanyak 88 orang $(51,5 \%)$. Hal ini menunjukkan bahwa mayoritas responden adalah perempuan. Karakteristik responden berdasarkan program untuk mengetahui program yang dipilih oleh mahasiswa. Tabel 3 menunjukkan bahwa program reguler pagi sebanyak 86 orang $(50,3 \%)$, dan program regular sore sebanyak 85 orang $(49,7 \%)$. Hal ini menunjukkan bahwa mayoritas responden adalah berasal dari program reguler pagi. 
Karakteristik responden berdasarkan indeks pretasi komulatif untuk mengetahui nilai yang didapat oleh responden. Tabel 3 menunjukkan bahwa ratarata IPK laki-laki program reguler pagi adalah 3,49, pada perempuan program regular pagi rata-rata IPK yaitu 3,65, pada laki-laki program regular sore rata-rata IPK yaitu 3,57 serta pada perempuan program regular sore rata-rata IPK yaitu 3,48 . Hal ini menunjukkan bahwa perempuan program regular pagi memiliki ratarata IPK tertinggi.

Statistik Deskriptif dalam penelitian ini disajikan untuk memberikan informasi tentang karakteristik variabel penelitian, antara lain nilai minimum, maksimum, mean dan standar deviasi. Untuk mengukur nilai sentral dari suatu distribusi data umumnya digunakan pengukuran rata-rata (mean), sedangkan untuk mengukur perbedaan nilai data yang diteliti dengan nilai rata-ratanya digunakan standar deviasi. Statistik deskriptif dalam penelitian ini dapat dilihat dalam Tabel 4 di bawah ini.

Tabel 4.

Hasil Uji Statistik Deskriptif

\begin{tabular}{lccccc}
\hline \multicolumn{1}{c}{ Variabel } & $N$ & Min. & Max. & Mean & Std. Deviation \\
\hline Keterampilan $\left(\mathrm{X}_{1}\right)$ & 171 & 9,00 & 35,67 & 26,426 & 8,206 \\
Pengetahuan $\left(\mathrm{X}_{2}\right)$ & 171 & 6,00 & 23,26 & 17,655 & 5,537 \\
Karakter $\left(\mathrm{X}_{3}\right)$ & 171 & 9,00 & 35,02 & 26,498 & 8,262 \\
Tingkat Profesionalisme Dosen & 171 & 12,00 & 46,03 & 34,637 & 11,154 \\
Akuntansi $(\mathrm{Y})$ & & &
\end{tabular}

Sumber: Data diolah, 2018

Berdasarkan Tabel 4 dijelaskan bahwa nilai dari statistik deskriptif yang meliputi nilai minimum, maksimum, rata-rata dan standar deviasi dengan $\mathrm{N}$ sebanyak 171 responden yang diolah. Nilai minimum variabel keterampilan sebesar 9,00dan nilai maksimum sebesar 35,67. Nilai rata-rata variabel keterampilan sebesar 26,426 dimana nilai tersebut mendekati nilai maksimal 
artinya keterampilan yang dimiliki oleh dosen. Deviasi standar variabel keterampilan adalah 8,206 yang memiliki makna dimana terjadi penyimpangan nilai keterampilan pada nilai rata-ratanya sebesar 8,206.

Nilai minimum variabel pengetahuan sebesar 6,00 dan nilai maksimum sebesar 23,26. Nilai rata-rata variabel pengetahuan sebesar 17,655 dimana nilai tersebut mendekati nilai maksimal artinya pengetahuan yang dimiliki oleh dosen cenderung tinggi. Deviasi standar variabel pengetahuan adalah 5,537 yang memiliki makna dimana terjadi penyimpangan nilai pengetahuan pada nilai rataratanya sebesar 5,537.

Nilai minimum variabel karakter adalah sebesar 9,00 dan nilai maksimum sebesar 35,02. Nilai rata rata variabel karakter sebesar 26,498 dimana nilai tersebut mendekati nilai maksimal artinya karakter yang dimiliki oleh dosencenderung tinggi. Deviasi standar variabel karakter adalah 8,262 yang memiliki makna dimana terjadi penyimpangan nilai kepercayaan pada nilai rataratanya sebesar 8,262 .

Nilai minimum dari variabel profesinalisme dosen sebesar 12,00 dan nilai maksimum sebesar 46,03. Nilai rata-rata variabel profesionalisme dosen sebesar 34,637 dimana nilai tersebut mendekati nilai maksimal artinya profesionalisme dosen cenderung tinggi. Deviasi standar variabel profesionalisme dosen adalah 11,154 yang memiliki makna dimana terjadi penyimpangan nilai profesionalisme dosen pada nilai rata-ratanya sebesar 11,154 . Pengujian normalitas distribusi data populasi dilakukan dengan menggunakan statistic kolmogorov-smirnov. Apabila Asymp. Sig (2 tailed) $>\alpha(0,05)$ maka dikatakan data terdistribusi normal. 
Tabel 5.

Hasil Uji Normalitas

\begin{tabular}{ccc}
\hline No & Persamaan & Asymp. Sig \\
\hline 1 & $\mathrm{Y}=\alpha+\beta_{1} X_{1}+\beta_{2} X_{2}+\beta_{3} X_{3}+e$ & 0,081 \\
\hline Sumber: Data diolah, 2018
\end{tabular}

Berdasarkan Tabel 5 diatas, data sudah terdistribusi secara normal. Hal ini ditunjukan dengan nilai unstandardized Residual pada 0,081 yang lebih besar 0,05. Hal ini berarti data residual berdistribusi secara normal, karena nilai signifikasinya lebih besar dari 0,05. Model regresi yang baik seharusnya tidak terjadi korelasi diantara variabel bebas. Model regresi yang bebas dari multikolinearitas adalah memiliki tolerance variabel bebas yang lebih dari $10 \%$ atau 0,10 atau sama dengan variance inflation factor (VIF) kurang dari 10. Hasil uji multikolinearitas disajikan pada Tabel 6 di bawah ini.

Tabel 6.

Hasil Uji Multikolinearitas

\begin{tabular}{|c|c|c|}
\hline Variabel Penelitian & Nilai Tolerance & Nilai VIF \\
\hline Keterampilan $\left(\mathrm{X}_{1}\right)$ & 0,251 & 3,987 \\
\hline Pengetahuan $\left(\mathrm{X}_{2}\right)$ & 0,232 & 4,303 \\
\hline $\operatorname{Karakter}\left(\mathrm{X}_{3}\right)$ & 0,239 & 4,184 \\
\hline
\end{tabular}

Sumber: Data diolah, 2018

Hasil uji multikolinearitas pada Tabel 6 diatas menampilkan bahwa nilai tolerance pada masing-masing variabel lebeih besar dari $0,10(>0,10)$ dan nilai VIF pada masing-masing variabel kurang dari 10(<10). Dapat disimpulkan bahwa data penelitian terbebas dari multikolinearitas.

Uji heteroskedastisitas dalam penelitian ini dilakukan dengan menggunakan uji glejser yang dilihat dari nilai probabilitas signifikannya di atas tingkat kepercayaan 5\%. Hasil uji heteroskedastisitas disajikan pada Tabel 7 di bawah ini. 
Tabel 7.

Hasil Uji Heteroskedastisitas

\begin{tabular}{lcc}
\hline \multicolumn{1}{c}{ Variabel Penelitian } & Sig. & Keterangan \\
\hline Keterampilan $\left(\mathrm{X}_{1}\right)$ & 0,285 & Bebas Heteroskedastisitas \\
Pengetahuan $\left(\mathrm{X}_{2}\right)$ & 0,258 & Bebas Heteroskedastisitas \\
Karakter $\left(\mathrm{X}_{3}\right)$ & 0,103 & Bebas Heteroskedastisitas \\
\hline
\end{tabular}

Sumber: Data diolah, 2018

Berdasarkan Tabel 7 diatas maka dapat dilihat bahwa nilai Sig. dari masing-masing variabel tersebut diatas 0,05 sehingga seluruh variabel tersebut dapat dikatakan terbebas dari heteroskedatisitas.

Analisis regresi linear berganda diolah dengan bantuan SPSS. Hasil pengujian disajikan pada Tabel 8 berikut ini.

Tabel 8.

\section{Hasil Analisis Regresi Linear Berganda}

\begin{tabular}{|c|c|c|c|c|c|}
\hline \multirow[t]{2}{*}{ Model } & \multicolumn{2}{|c|}{$\begin{array}{c}\text { Unstandarized } \\
\text { Coefficient }\end{array}$} & \multirow{2}{*}{$\begin{array}{c}\text { Standardized } \\
\text { Coefficient } \\
\text { Beta }\end{array}$} & \multirow[t]{2}{*}{$t$} & \multirow[t]{2}{*}{ Sig. } \\
\hline & $B$ & Std. Error. & & & \\
\hline Constant & $-1,966$ & 0,791 & & $-2,487$ & 0,140 \\
\hline Keterampilan & 0,425 & 0,054 & 0,313 & 7,829 & 0,000 \\
\hline Pengetahuan & 0,640 & 0,084 & 0,318 & 7,652 & 0,000 \\
\hline Karakter & 0,531 & 0,055 & 0,393 & 9,608 & 0,000 \\
\hline $\begin{array}{l}\text { Adjusted } R_{\text {square }} \\
F_{\text {hitung }}: 776,71 \\
\text { Sig } F_{\text {hitung }}: 0,0\end{array}$ & ,932 & & & & \\
\hline
\end{tabular}

Berdasarkan Tabel 8 maka disusun persamaan regresi linear berganda sebagai berikut.

$$
Y=-1,966+0,425 X_{1}+0,640 X_{2}+0,531 X_{3}
$$

Nilai konstanta $(\alpha)$ sebesar -1,966 memiliki arti jika variabel keterampilan, pengetahuan, dan karakter dinyatakan konstan pada angka 0, maka nilai tingkat prosfesionalisme dosen sebesar -1,966. Koefisien regresi $\beta_{1}$ untuk variabel keterampilan sebesar 0,425 memiliki arti bahwa jika variabel keterampilan meningkat maka akan menyebabkan peningkatan pada persepsi mahasiswa terhadap tingkat profesionalisme dosen, dengan asumsi variabel bebas lainnya 
dianggap konstan. Koefisien regresi $\beta_{2}$ untuk variabel pengetahuan sebesar 0,640 memiliki arti bahwa jika variabel pengetahuan meningkat maka akan menyebabkan peningkatan pada persepsi mahasiswa terhadap tingkat profesionalisme dosen, dengan asumsi variabel bebas lainnya dianggap konstan.

Koefisien regresi $\beta_{3}$ untuk variabel karakter sebesar 0,531 memiliki arti bahwa jika variabel karakter meningkat maka akan menyebabkan peningkatan padapersepsi mahasiswa terhadap tingkat profesionalisme dosen, dengan asumsi variabel bebas lainnya dianggap konstan.

Koefisien determinasi yang digunakan pada analisis regresi linear berganda adalah nilai Adjusted $\mathrm{R}^{2}$. Hasil analisis menunjukkan bahwa nilai Adjusted $R^{2}$ sebesar 0,932. Ini berarti perubahan yang terjadi pada tingkat profesionalisme dosen dapat dijelaskan oleh keterampilan, pengetahuan dan karakter sebesar 93,2\% sedangkan sisanya dijelaskan oleh faktor lain yang tidak diuji dalam penelitian ini. Tabel 8 menunjukkan bahwa nilai $\mathrm{F}_{\text {hitung }}$ yang diperoleh adalah 776,715dengan signifikansi 0,000. Signifikansi ini jelas lebih kecil dari Alpha $(\alpha=0,05)$ maka model regresi telah memenuhi prasyarat kelayakan model regresi.

Hipotesis pertama menyatakan bahwa keterampilan berpengaruh positif terhadap tingkat profesionalisme dosen. Pengujian pada hipotesis pertama menunjukkan bahwa nilai koefisien regresi keterampilan sebesar 7,829 dengan nilai signifikansi 0,00 yaitu lebih kecil dari 0,05 . Berdasarkan hal tersebut maka hipotesis pertama diterima, artinya keterampilan berpengaruh positif terhadap tingkat profesionalisme dosen. 
Hipotesis kedua menyatakan bahwa pengetahuan berpengaruh positif terhadap tingkat profesionalisme dosen. Pengujian pada hipotesis kedua menunjukkan bahwa nilai koefisien regresi pengetahuan sebesar 7,652 dengan nilai signifikansi 0,00 yaitu lebih kecil dari 0,05. Berdasarkan hal tersebut maka hipotesis kedua diterima, artinya pengetahuan berpengaruh positif terhadap tingkat profesionalisme dosen.

Hipotesis ketiga menyatakan bahwa karakter berpengaruh positif terhadap tingkat profesionalisme dosen. Pengujian pada hipotesis ketiga menunjukkan bahwa nilai koefisien regresi karakter sebesar 9,608 dengan nilai signifikansi 0,00 yaitu lebih kecil dari 0,05 . Berdasarkan hal tersebut maka hipotesis ketiga diterima, artinya karakter berpengaruh positif terhadap tingkat profesionalisme dosen.

Berdasarkan Tabel 8 diperoleh nilai $\mathrm{t}_{\text {hitung }}$ untuk variabel keterampilan 7,829 dan nilai signifikansi uji t sebesar 0,00 lebih kecil dari $\alpha=0,05$ dan nilai koefisien regresi sebesar 0,425 maka $\mathrm{H}_{1}$ diterima. Hasil ini mendukung hipotesis pertama yang menyatakan bahwa keterampilan berpengaruh positif terhadap tingkat profesionalisme dosen. Hasil penelitian ini menunjukan bahwa keterampilan dosen berpengaruh positif terhadap persepsi mahasiswa tentang tingkat profesionalisme dosen akuntansi.Kaitannya dengan teori pengharapan yaitu harapan seorang mahasiswa untuk mampu mendapatkan keterampilan soft skill yang mampu menunjang hard skill mahasiswayang didapat dari pengajaran dosen mereka. Melalui peningkatan keterampilan yang mampu menunjang ilmu pendidikan akuntansi maka tentunya hal itu dapat menjadi nilai tambah bagi para 
mahasiswa dalam persaingan dunia kerja. Dengan meningkatkan keterampilan mahasiswa maka hal ini menunjukan seberapa tingginya tingkat profesionalisme dosen akuntansi selaku pendidik di Universitas Udayana.

Berdasarkan Tabel 8 diperoleh nilai $t_{\text {hitung }}$ untuk variabel pengetahuan sebesar 7,652 dan nilai signifikansi uji t sebesar 0,00 lebih kecil dari $\alpha=0,05$ dan nilai koefisien regresi sebesar 0,640 maka $\mathrm{H}_{2}$ diterima. Hasil ini mendukung hipotesis kedua yang menyatakan bahwa pengetahuan berpengaruh positif terhadap tingkat profesionalisme dosen akuntansi.

Hasil penelitian ini menunjukan bahwa pengetahuan dosen berpengaruh positif terhadap persepsi mahasiswa tentang tingkat profesionalisme dosen akuntansi.Hubungan dengan teori pengharapan yaitu harapan mahasiswa tentang seberapa bermanfaat dan bergunanya pengetahuan yang mahasiswa dapatkan tentang pengetahuan akuntansi maupun juga pengetahuan diluar akuntansi seperti pengetahuan umum dan juga pengetahuan bisnis.Apabila pengetahuan dikembangkan dengan maksimal tidak hanya terfokus saja pengetahuan dasar (Akuntansi) tetapi juga pengetahuan bisnis, pengetahuan umum mampu dikembangkan dengan baik maka persepsi mahasiswa tentang proses belajarmengajar di perguruan tinggi akan meningkat. Mahasiswa akan mampu menerima pelajaran dengan baik dan senang mengikuti pelajaran dan secara langsung akan meningkatkan indeks prestasi kumulatif mahasiswa. Hasil penelitian ini mendukung (Pramesti dan Palupi, 2016), Nurchayati (2012) yang membuktikan bahwa pengetahuan dosen berpengaruh positif terhadap persepsi mahasiswa tentang tingkat profesionalisme dosen akuntansi. Berdasarkan Tabel 8 diperoleh 
nilai $t_{\text {hitung }}$ untuk variabel karakter sebesar 9,608 dan nilai signifikansi uji t sebesar 0,00 lebih kecil dari $\alpha=0,05$ dan nilai koefisien regresi sebesar 0,531 maka $\mathrm{H}_{3}$ diterima. Hasil ini mendukung hipotesis ketiga yang menyatakan bahwa karakter berpengaruh positif terhadap tingkat profesionalisme dosen akuntansi.

Hasil penelitian ini menunjukan bahwa karakter dosen berpengaruh positif terhadap persepsi mahasiswa tentang tingkat profesionalisme dosen akuntansi. Kaitannya dengan teori pengharapan yaitu karakter seorang dosen dilihat dari suatu kebiasaan, etika dan bagaimana cara seorang dosen memotivasi mahasiswanya dalam usaha pengembangan dan peningkatan mutu dan kualitas sumber daya manusianya. Apabila karakter ditanam dan dikembangkan dengan baik seperti etika, motivasi dan sikap jujur maka itu berarti bahwa dosen akuntansi di Universitas Udayana bekerja secara profesional mampu mengembangkan budi pekerti bagi setiap pribadi mahasiswa itu sendiri. Mahasiswa akan merasa nyaman dan senang mengikuti pelajaran karena dosen memiliki etika dan kesopanan yang baik dan mahasiswa akan mampu meningkatkan indeks prestasi kumulatif mareka. Hasil penelitian ini mendukung Rahmalia (2013), Nurdin (2013) yang membuktikan bahwa karakter dosen berpengaruh positif terhadap persepsi mahasiswa tentang tingkat profesionalisme dosen akuntansi.

Penelitian ini mampu menambah wawasan ilmu pengetahuan mengenai teori pengharapan (expectancy theory) serta pengaruh keterampilan, pengetahuan, dan karakter terhadap tingkat profesionalisme dosen akuntansi. Hasil uji dalam penelitian ini mendapatkan hasil bahwa apabila dosen akuntansi melakukan tugas 
secara professional maka mahasiswa akan merasa nyaman dalam mengikuti proses belajar-mengajar dan akan senang dalam melakukan kegiatan yang ada di dalam kampus.

Penelitian ini diharapkan mampu untuk memberikan berbagai pertimbangan kepada dosen agar mampu meningkatkan kinerjanya untuk memajukan Fakultas Ekonomi Dan Bisnis Universitas Udayana dalam kaitannya dengan faktor-faktor diatas. Selain itu penelitian ini juga diharapkan memberikan suatu informasi untuk penelitian selanjutnya, guna untuk penyempurnaan penelitian mengenai hal sejenis.

\section{SIMPULAN}

Keterampilan dosen berpengaruh positif terhadap persepsi mahasiswa tentang tingkat profesionalisme dosen akuntansi di Universitas Udayana, yang berarti tingkat keterampilan yang profesional akan mempengaruhi persepsi mahasiswa akuntansi di Universitas Udayana tentang kualitas pendidikan yang didapatkan dan akan mampu meningkatkan kemampuan berpikir, kemampuan menganalisa dan kemampuan berbicara. Pengetahuan dosen berpengaruh positif terhadap persepsi mahasiswa tentang tingkat profesionalisme Dosen Akuntansi di Universitas Udayana, yang berarti melalui pengetahuan yang luas akan mampu memberikan wawasan dan membuka cara pandang mahasiswa akan ilmu pengetahuan terutama pada bidang akuntansi dan didampingi dengan pengetahuan umum dan bisnis yang akan mempengaruhi persepsi mahasiswa akuntansi di Universitas Udayana tentang kualitas pendidikan yang didapatkan 
Karakter dosen berpengaruh positif terhadap persepsi mahasiswa tentang tingkat profesionalisme dosen akuntansi di Universitas Udayana, yang berarti melalui pendidikan karakter yang tepat maka akan mampu memberikan suri teladan bagi mahasiswa dalam beretika di masyarakat dan dunia kerja. Bagi pihak yang ingin melakukan penelitian lebih lanjut dapat meneliti pada perguruan tinggi negeri lain di Bali atau pada perguruan tinggi swasta di Bali serta diharapkan menggunakan variabel lain seperti gender, intelektual, spritual, sikap, perilaku dan adat budaya. Penelitian selanjutnya dapat juga menambah jumlah populasi dan sampel yang digunakan sebagai responden agar hasil dari penelitian berikutnya dapat digunakan secara lebih luas. Bagi dosen diharapkan untuk beradaptasi dan bersosialisasi dengan mahasiswa sehingga tercipta komunikasi dan kondisi yang baik. Dosen juga diharapkan untuk meningkatkan pengembangan tingkat kreatifitas mahasiswa lewat festival ekonomi kampus dan dosen diharapkan datang tepat waktu pada saat mengajar.

\section{REFERENSI}

Alizamar. Nasbahry Couto. 2017. Psikolog Persepsi dan Desain Informasi. Jogjakarta. Buku Beta Jogja

Idrus, Y. M. (2013) Pengaruh Profesionalisme Akuntan Pendidik dan Metode Pembelajaran Terhadap Tingkat Prestasi Mahasiswa. Universitas Hasanuddin Makassar. doi: 10.1037/a0028181.

Istiqomah, D. A. (2015) 'Perbandingan Persepsi Mahasiswa Akuntansi Tentang Profesionalisme Akuntan Pendidik', Jurnal Akuntansi, 1(1), pp. 1-9. Available at: http://eprints.perbanas.ac.id/611/1/ARTIKEL ILMIAH.pdf.

Nurchayati (2012) 'Persepsi Mahasiswa Terhadap Profesionalisme Dosen Akuntansi Fakultas Ekonomi Universitas 17 Agustus 1945 Semarang', Serat Acitya - Jurnal Ilmiah, 1(1), pp. 1-10. Available at: 
https://jurnal.untagsmg.ac.id/index.php/sa/article/viewFile/13/102.

Nurdin, R. (2013) Persepsi Mahasiswa Akuntansi Terhadap Profesionalise Akuntan Pendidik pada Perguruan Tinggi Swasta di Makassar. Universitas Hasanuddin Makassar.

Pramesti, H. and Dhewi, W. A. P. (2016) 'Persepsi Mahasiswa Terhadap Profesionalisme Dosen di Lingkungan Perguruan tinggi Swasta di Surakarta', Jurnal Ekonomi dan Kewirausahaan, 6(1), pp. 51-66.

Pramesti, H. and Palupi, D. A. P. (2016) 'Pengaruh Keahlian, Pengetahuan, Sikap dan Etika Terhaap Profesionalisme Dosen Akuntansi Perguruan Tinggi Swasta di Surakarta', Jurnal Riset Akuntansi dan Keuangan, 3(1), pp. 3436.

Rahmalia, S. (2013) Persepsi Akuntan Pendidik dan Akuntan Publik Terhadap Kualitas Akuntan Menghadapi Tuntunan Profesionalisme di Era Globalisasi. Universitas Sebelas Maret.

Riddiniyah, I. (2013) 'Pengaruh Persepsi Siswa Tentang Kompetensi Profesionalisme Guru Terhadap Motivasi Belajar dan Prestasi Belajar Mata Diklat Akuntansi', Journal of Accounting and Business Education, 1(4), pp. $1-18$.

Robbins, S.P.2001 Perilaku Organisasi. Jakarta:Prenhallindo

Safford, S. \& Kershaw, A. (1998) 'Sense and Sensibility in a Changing World: managing change and institutional transformation', Perspektive, 2(3).

Tarigan. 2017. Menyimak Sebagai Suatu Keterampilan Berbahasa. Yogkyakarta. Boom. H:134-144.

Undang-undang, Republik Indonesia, Nomor 14 Tahun (2005), tentang Guru dan Dosen

Virgana (2014) 'Persepsi Mahasiswa pada Profesionalisme Dosen, Minat Belajar dan Pemahaman Konsep Diferensial', Faktor Jurnal Ilmiah Kependidikan, 4(April), pp. 167-176. 